\title{
Observations of the Birds of Candle Lake
}

\section{By Frank Brazier, Regina}

Candle Lake is a relatively large, deep lake located in northern Saskatchewan at lat. $53^{\circ} 45^{\prime} N$., long. $105^{\circ} 15^{\prime}$ some 30 miles nonth-east of Emma Lake and about 60 miles by rolad from Prince Albert. Map sheet No. 73-H-14 (Candle Lake Forestry Map-scale 1" to 1 mile), available from the Department of Natural Resources at Regina or Prince Albert for 75 cents, is a necessity for anyone contemplating a visit to the area.

A mixed forest of evergreen and deciduous trees surrounds the lake, and away from the roads the walking ranges from difficult to impossible, owing to dense ground cover, old tangled burns, muskeg, swamp, etc. The lake teems with fish and the woods abound with wildlife, particularly birds. Our observations were made travelling by car and on foot along both shores of the lake in the near vicinity (including Torch Lake and Little Sandy Lake).

The birds listed in this ar.icle were logged during a 2-week period (June 28-July 13, 1958) spent in the area. Observers included Elmer Fox, Reg Fox and myself. The 90 species that we identified at Candle Lake during this time by no means exhaust the kinds of birds there, for we are confident that given more time to investigate the area in greater detail we should have been able to add cthers to the list.

During the two weeks, five Common Loons were seen-four at Little Sandy Lake cne evening, and a solitary adult on Candle Lake later.

The grebe family were represented by four of Saskatchewan's five grebes: the Red-necked were common on Candle Lake and a pair with downy young were seen on Torch Lake; one adult Horned Grebe was seen on Torch Lake, where we also noted an adult Western Grebe with a single downy young, and a single Pied-billed Grebe.

Groups of adult White Pelicans were seen in varying numbers daily, the largest group consisting of nine. A breeding colony is reported at Candle Lake, and although we did not see the colony ourselves, Fox noted young pelicans on a brief visit made later to the lake.
Great Blue Herons were observed on three occasions and an American Bittern once. We saw eight species of ducks, Mallards with little fleets of downy young being common, while a few Ring-necked Ducks, Canvasbacks and Common Goldeneyes all were seen with downy young. A few adult Lesser Scaup, one male Pintail, two White-winged Scoters, and two Common Mergansers were also noted.

Birds of prey were sparsely observed, a single Cooper's Hawk, Broad-winged Hawk and Osprey being all we saw besides a few Sparrow Hawks and three Bald Eagles. The Bald Eagle's eyrie was in an old spruce on a small island in Candle Lake: there were two adults and one eaglat the size of a Great Horned Owl. According to local report, a pair of eagles has nested here since 1921. The isliand with the eagle's eyrie is rimmed with tall spruce, with two or three clumps of tall spruce in the middle. These appear to have survived a fire which siwept the entire island, and the mass of fallen trees. branches and stumps is totally covered with a dense growth of brambles festconed with spider webs. Because of the nature of the ccver, the island swarms with breeding birds, from eagles to warblers.

The Ruffed Grouse (one individual) was the only grouse seen. We know that it breeds in the area because Lyle Lensen, the D. N. R. Conservation Officer there, reported a nest with a clutch of eggs.

Two species of rails were noted: Virginia Rails were heard at Torch Lake, and one adult Sora was seen on a nearby slough. Four adult American Coots, one with a flotilla of downy young, were seen on Torch Lake.

Killdeers were seen twice, while the sandpipers were-represented by Common Snipe (recognized by its unmistakeable winnowing); Spotted Sandpipers were observed on the beaches, and two Greater Yellowlegs perched on the tips of two 20-foot spruces on the road between White Gull and Candle Lakes.

Gulls and terns were well represented. Ring-billed Gulls were common, with fewer Clalifornia Gulls and small numbers of both the 
Franklin's Gull and the similar Bonaparte's Gull. The Common Tern was common and the Black Tern was abundant in breeding colonies on Torch Lake and nearby marshes.

Two Great Horned Owls were seen on the road to White Gull Lake one evening, and another smaller owl noted but too briefly to determine species-perhaps the Boreal Owl. The Common Nighthawk was noted at Little Sandy Lake and Candle Lake. We had a long, clise view of a male Ruby-throated Hummingbird at rest late one afternoon, his throat alternately ruby-red and velvet-black as he turned his head in the sunshine. One Belted Kingfisher was seen where the road to White Gull Lake crosses Torch River.

We noted six species of woodpeckers: the magnificent Pileated once, the Yellow-shafted Flisker commonly (one nest), Yellow-bellied Sapsuckens commonly (two nests with young), two Hairy Woodpeckers at nest with young, and Downy Woodpeckers (also nesting). We saw one Black-backed Three-toed Woodpecker at the same time as the Horned Owls were observed.

The flycatchers were well represented. Eastern Kingbirds were common, one family with four bobtailed, frog-faced young living in a dead tree tangle in a slough; two Eastern Phoebes were noted, and a nest with four eggs found (under a bridge of course); Least Flycatchers were common; two Western Wood Pewees were noted, and one Olivesided Flycatcher.

Swallows were many in number, but only of two species. Tree Swallows were common, and two nesting sites were found; Barn Swallows were abundint, three nesting sites being found-one with eggs, one with young, the third not examined.

The carvines were not numerous, but the few observed were noisy. A few Gray Jays, some of them bobtailed young, were encountered on the road to Hanin Creek. A few adult Common Ravens croaked, fluted, gargled and wheezed around Candle Lake while a few Common Crows with fledgling young were usually in evidence.

We found Black-capped Chickadees, once with fledglings, but only adult Boreal Chickadees. One Red- breasted Nutatch was seen and one Brown Creeper.

Of the Wrens, only one Shortbilled Marsh Wren was seen at the west end of Torch Lake in a hay meadow near clumps of ebushes, typical habitat for this wren.

The trushes were represented by Robins, which were common and often seen carrying food, while fledglings were also observed; a few Hermit Thrushes; one Veery with food; and six Mountain Bluebirds seen on a burn near White Gull Lake.

The only kinglet seen was Rubycrowned, it being common and breeding (one family seen with young).

We did not see Bohemian Waxwings but the Cedar Waxwing was common. We saw no shrikes or starlings, and only cne vireo, the Redeyed which was common and breeding, three nests with eggs being located.

We identified nine species of wood warblers, fewer than expected. A few Tennessees were seen, one Cape May in the birch around the D. N. R. Headquarters, a few Myrtles, two Blackburnian (one adult male on the eagle island, and one adult female carrying food near the D.N.R. headquarters), two Ovenbirds' were noted near D. N. R., while a few Northern Waterthrushes were seen along the marshy east shore of Candle Lake by Hayes' Camp. A few Mourning Wlarblers were seen, including three agitated adults - two on the eagle island and one near Hayes' Camp. Yellowthroats were common near water, one adult male observed carrying food. (This one systematically attacked the cattails, tearing the seed heads apart until a small white moth flew from one which was seized). One Wilson's was seen, concluding a somewhat unsatisfactory warbler list.

Two House Sparrows were seen, and only three species of icterids. Both the Redwinged Blackbird and Common Grackle were abundant and breeding (nests with eggs or young found in both cases); the Brownheaded Cowbird was common.

The fringillids were well represented (11 species): two Purple Finches, a few Pine Siskins and American Goldfinches, one Red Crossbill, three LeConte's Sparrows (in a hay meadow near Torch Lake), 
a few Slate-colored Juncos, abundant Chipping Sparrows (young, nest with eggis), a few Clay-colored Sparrows (young. nest with eggs), many White-throated Sparrows (common -nest with eggs found), three Swamp Sp:arrows (two adults feeding a fledgling), and abundant Song Sparrows. We had hoped for a better sparrow list also.

Without exception the species observed are summer residents, on their breeding grounds. It will be noted that some of the species on our list are breeding well beyond the breeding ranges given for them in the standard handbooks.

\section{BITTERN BEHAVIOR} By Joyce Dew

Saskatchewan Museum of Natural History

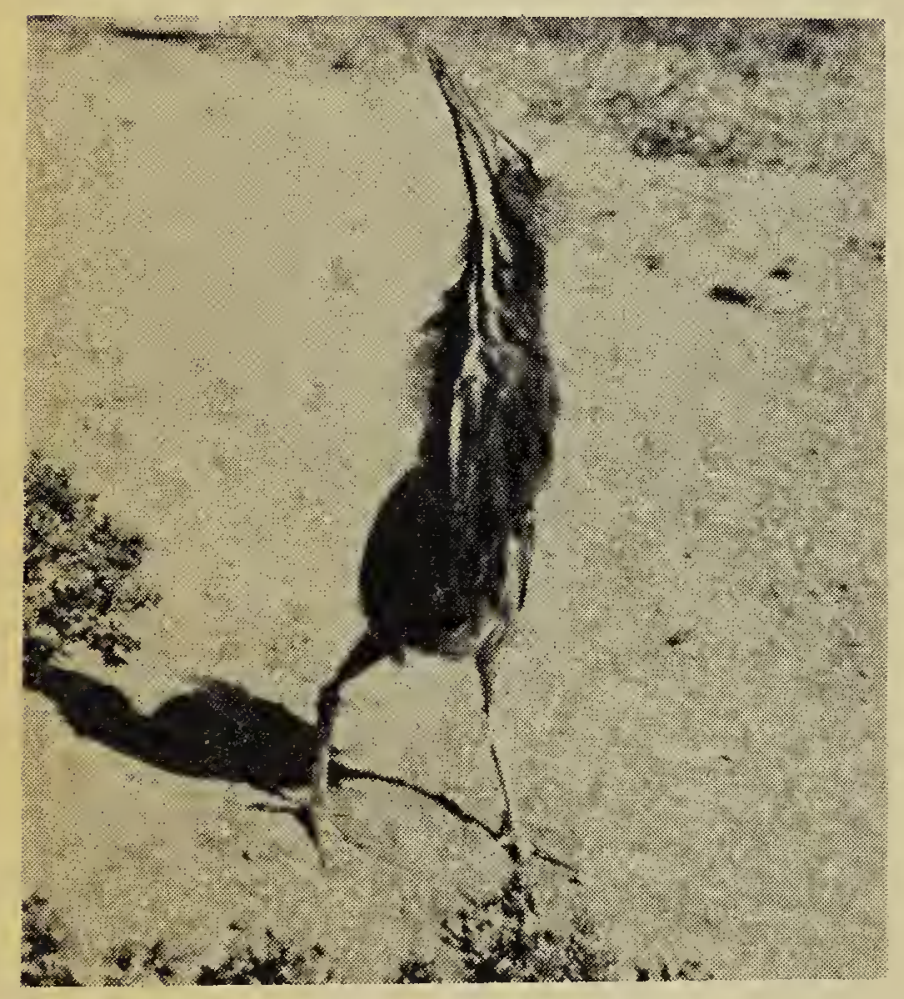

AMERICAN BITTERN

The prototype of a bittern, standing upright and motionless, well camouflaged in the reeds, was firm in my mind. It came somewhat as a shock then, when I saw my first bittern* behaving in a bittern-like manner in very unbittern-like surroundings. Certainly this bird could not have been more noticeable. This was contrary to all I had been led to expect from its "camouflage" behavior. The place was a puddle of water completely devoid of cover beside old No. 1 highway west of Moose Jaw. The bird stood upright and alert in the middle of the puddle while I sped past, slowed the car down, shifted it into reverse, came alongside and sat and stared. The bird had one eye turned toward me and the two of us remained completely motionless for some seconds. Then the bird leaned forward, took several siteps tcward shore, assumed a moticnless upright position for several seconds, took several more steps, pause again. Once on shore it tcok several steps, assumed its motionless upright positicn then with no apparent haste flew away. Fred Lahrman of the IMseum staff reports having seen a bittern behave in like manner. When caught off guard in the open it stood bolt upright beside a water trough. [Ed.].

* American Bittern (Bctaurus lentiginosus

\section{MORE BLACK DUCK RECORDS}

Since the publication of Lucy Murray's article on the Black Duck in Siskatchewan (Blue Jay, XVI: 109-111), the following records of the cccurrence of the Black Duck in this province have been brought to our attention.

It should also be noted that two of the four Black Ducks banded at Yorkton, 1945, were banded by Stuart Houston, and two by J. H. Wilson (see Blue Jay, XVI, p. 109.).

Ducks Unlimited: Adult male Black Ducks banded by biologist Tom Sterling at Pel Lake, Wynyard, as follows: July 15,1955 (1), Aug. 16, 1955 (1), July 23, 1956 (1), July 9, 1957 (2), July 19, 1957 (7), July 11, 1958 (4), July 23, 1958 (2). Also one adult male banded at Kutawagan Lake, Wynyard, by Tom Sterling, July 9, 1958, and one adult male (banded in Wayne County, Michigan) trapped and released by him July 23, 1956. The fact that all Black Ducks banded by Sterling were adult males is probably due to their being bander in the drive banding of flightless ducks on the two lakes that have become notable concentration areas for mculters. - B. W. Cartwright.

Canadian Wildlife Service: Black Ducks banded as fcllows- 1950 ( 3 adult males, 1 adult female), 1952 ( 2 adult males), 1955 ( 2 sex and age unknown), 1956 (1), 1958 (1 Mculting adult drake, caught at Bea ufield Slough, 23 miles north of Kindersley, July 2); s $\mathrm{pring}$ report by Tom Sterling of Ducks Unlimited of a Black Duck flying with a Mallard female east cf Saskatoon in April or May, 1958; fall (Sept.-Oct.) records for Kindersley are as follows-1956 ( 2 flying adult drakes caught in bait traps), 1957 ( 1 adult drake in bait trap and 1 shot by hunter), 1958 ( 1 adult drake in bait trap and 2 seen in Teo Lake Community Pasture: one adult drake Mallard $X$ Black Duck hybrid caught in bait traps, Oct. 8).-J. B. Gollop, Alex Dzubin.

Maurice Street, Nipawin: 2 birds seen May 16, 1947; single birds seen on May 18, 1951 , and May 22, 1952; also noted at Candle Lake, July 31, 1944 ( 2 males).

Bill Anaka, Spirit Lake: One observed September 26, 1954. 